\title{
EVALUATION OF ELECTRONIC DOCUMENTATION OF THE NURSING PROCESS BASED ON THE CLASSIFICATION OF NURSING DIAGNOSES AND THE ICNP DICTIONARY
}

Alicja Kamińska A,B,C,D,F, Anna Majda, B,C,D,E,F, Joanna Zalewska-Puchała ${ }^{\mathrm{B}, \mathrm{C}, \mathrm{D}, \mathrm{E,F}, \mathrm{F}}$, Iwona Bodys-Cupak B,C,D,E,F, Joanna Łatka,B,C,D

Laboratory of Theory and Fundamentals of Nursing, Faculty of Health Sciences, Jagiellonian University Medical College, Cracow, Poland

Authors' contribution:

A. Study design/planning • B. Data collection/entry $\bullet$ C. Data analysis/statistics $\bullet$ D. Data interpretation $\bullet$ E. Preparation of manuscript $\bullet$ F. Literature analysis/search $\bullet$ G. Funds collection

\author{
Address for correspondence: \\ Dr Alicja Kamińska \\ Laboratory of Theory and Fundamentals \\ of Nursing \\ Faculty of Health Sciences \\ Jagiellonian University Medical College \\ Cracow, Poland \\ e-mail: alicja.kaminska@uj.edu.pl \\ SUBMITTED: 28.07 .2021 \\ ACCEPTED: 19.09 .2021 \\ DOI: https://doi.org/10.5114/ppiel.2021.113783
}

\begin{abstract}
Introduction: In teaching nursing, new technologies are used as tools to support patient care and for the standardization of the nursing language, and as part of distance learning. At the Faculty of Health Sciences of the Jagiellonian University Medical College in Cracow, an attempt was made to implement electronic nursing medical documentation, based on the International Classification for Nursing Practice (ICNP $\left.{ }^{\circledast}\right)$ dictionary, for teaching as part of the Fundamentals of Nursing subject, implemented during the first year of studies in the field of Nursing.

Aim of the study: To evaluate the electronic documentation of the nursing process using the ICNP ${ }^{\oplus}$ dictionary, and to show the importance of the electronic patient record in documenting nursing practice and teaching.

Material and methods: 158 students of the first year of undergraduate studies in Nursing took part in the study. The study used an original questionnaire.

Results: The study proved that the technology used supports students in collecting data about patients, and to a lesser extent it facilitates the diagnosis of nurses and the development of care plans, as well as documenting their implementation, and ongoing and final evaluation. The difficulties can be explained by the lack of experience in patient care and only basic knowledge acquired during the first year of studies.

Conclusions: Students noticed the advantages and validity of keeping electronic documentation of the nursing process based on ICNP®, but its performance should be improved. Moreover, the students also pointed out some shortcomings of electronic patient records.

Key words: nursing students, ICNP, electronic nursing records.
\end{abstract}

\section{INTRODUCTION}

The use of information technology (IT) has recently increased in every area of human life. It has become irreplaceable in many fields of science, including engineering and technical sciences, exact and natural sciences, as well as medical and health sciences. When it comes to teaching nursing, new technological possibilities are used as part of distance learning or diversification of traditional education. Due to the growing use of IT, IT competencies are becoming an essential requirement for nurses, students, and nursing teachers.

The International Classification of Nursing Practices (ICNP®), based on the International Council of Nurses (ICN) guidelines, is becoming an integral part of the global informative infrastructure in health- care, health practice, and health policy worldwide. It is also an international standard for nursing terminology. Polish nursing must face the era of computerization so that the professional group of nurses is not digitally excluded and can perform new professional functions in the globalized IT world. According to D. Kilańska, "The implementation of an electronic health record (EHR) in nursing practice is a challenge for Polish nursing" [1, p. 69]. When starting work with the use of electronic medical documentation, it is worth taking advantage of the experience of the Center for Health Information Systems and the guidelines contained in the Regulation of the Minister of Health of November 9, 2015 on the types, scope and patterns of medical documentation and the method of its processing, as amended. It is also necessary to have a prepared documentation 
scheme for the needs of nursing (implemented in the DOROTHEA application).

The curricula of students majoring in nursing must take into account issues of e-health. Those teaching the profession must become leaders and undertake an important task - developing detailed e-health curricula (at the pre- and post-graduate level), integrating knowledge with everyday clinical practice and procedures, taking into account inter-professional communication in the IT system, equipping students of nursing universities and nurses with new skills and new professional competencies expected by employers [1-5]. Implementing the knowledge and skills to use the ICNP® International Classification of Nurs ing Practice is intended to allow for: 1) standardization of the vocabulary used by nurses, improvement of the quality of care and patient safety, supporting work with the nursing process method; 2) collection of information about the patient and his/her health status: physical, mental, social, cultural, and spiritual; 3) mutual understanding between nurses working in different conditions and cultures; 4) broadening of the knowledge of the relationship between nursing diagnosis, interventions, and outcomes of care; 5) development of databases enabling analysis; 6) providing guidelines for care; 7) standardization of nursing care plans; 8) identification of the necessary investment in nursing care and resource planning in daily practice; 9) collection of data on nursing, research development, and professionalization of nursing; and 10) collection, analysis, and sharing of data on adverse events [6]. Thanks to the efforts of the Polish Nursing Society (PTP), the Polish government purchased the ICNP dictionary license for Polish nurses. The Council for e-Health in Nursing was established at the Healthcare Information Systems Centre (CSIOZ). The Supreme Council of Nurses and Midwives, National Consultants in particular fields of nursing, supported the position of the PTP on the implementation of the ICNP classification. It is also recommended in the National Strategic Framework of the Ministry of Health until 2023. In 2015, the Minister of Health adopted guidelines for the project of electronic medical records in nursing. However, so far, the nursing community has not received the generally applicable electronic documentation of the nursing process as part of an integrated IT system in hospitals. Only in several or so hospitals, especially in northern Poland, was such documentation introduced as a pilot project [7]. "The actions taken are not known to the public as shown by few studies, require greater involvement in building knowledge on the use of electronic documentation in practice", says D. Kilańska [1, p. 69]. In response to these recommendations, as well as articles on care planning according to the international ICNP® standard in various areas of nursing [8-16], and lack of competencies in Nursing Informatics (NI) in both students and teaching and management staff at national and international level $[6,17,18]$, it was decided to take a closer look at this issue. Therefore, in 2017, an attempt was made at the Faculty of Health Sciences of the Jagiellonian University in Kraków to implement electronic nursing medical documentation based on the classification of nursing diagnoses and the ICNP ${ }^{\circledR}$ dictionary for teaching the Basics of Nursing during the first year of Nursing studies. All teachers teaching this subject have completed a course run by the ICN-accredited Centre for Research and Development ICNP $\left.{ }^{\circledast}\left(\mathrm{CBiR}_{\mathrm{R}} \mathrm{ICNP}\right)^{\circledast}\right)$ at the Medical University of Lodz.

\section{AIM OF THE STUDY}

The study aimed to evaluate electronic documentation of the nursing process based on the classification of nursing diagnoses and the use of the ICNP® dictionary in nursing medical records, and to show the importance of electronic patient records in documenting nursing practice and teaching.

\section{MATERIAL AND METHODS}

As part of the statutory project K/ZDS/007547 "Evaluation and validation of electronic documentation of the nursing process based on the ICNP ${ }^{\circledR}$ classification of nursing diagnoses" 2017-2019, a 5-year license of the Dorothea Software was purchased at the Medical University of Lodz under the name "Nursing documentation and support system ADPIECare 'Dorothea' to achieve the goals of teaching" (2017). The Dorothea application had the following functionalities, such as the ability to assess the patient's health status (Assessment), make nursing diagnoses (Diagnosis), plan nursing interventions (Planning/Nursing Interventions Classification, NIC), and ongoing and final evaluation (Evaluation/Nursing Outcomes, NOC). Thanks to this, it was possible to teach nursing students to document the nursing process. It is essential to mention that nursing students first used the NANDA, NIC, NOC classification during theory classes (lectures, exercises in the nursing skills laboratory) of Basics of Nursing, and then, after completion of this course, during the first practical classes. Also, as part of this course, the students were first trained in the ICNP ${ }^{\oplus}$ classification, the process of nurturing and working with e-documentation, and then during the practical classes they used the ICNP ${ }^{\circledR}$ classification.

Equipment (10 tablets, which were used to work with the application) was purchased, and a selfauthored questionnaire was developed to collect data on nursing students' opinions about electronic nursing medical records. The survey questionnaire consisted of 24 questions - 22 closed-ended and 
2 open-ended questions. The study was a post-study conducted in 2018/2019 and 2019/2020.

\section{RESULTS}

A total of 158 students of the first year of full-time first-cycle studies participated in the study. For over half of the respondents (66.5\%), the 7 -axis model of the ICNP classification structure was sufficiently clear.

The layout of the content included in the model turned out to be legible (36.7\%) for the largest number of students, as well as clear (27.8\%) and obvious (10.7\%). Unfortunately, almost one-third of the respondents found it difficult to understand (32.3\%), and for every seventh person, it required an additional description or explanation (14.5\%) (Fig. 1).

In the opinion of almost one-third of the respondents, searching for phrases was a simple task (29.1\%), but for more than half of the respondents it took a long time (58.2\%), and for $13.9 \%$ it turned out to be difficult (Fig. 2).

Most of the respondents indicated problems in formulating diagnoses, namely: spending a lot of time finding the searched phrase (55.5\%); difficulties in understanding diagnoses (34.2\%); and difficulties in their understanding and legibility (27.8\%). For onefourth of the respondents the diagnoses were insufficient $(24.7 \%)$ and too general (24\%), and for a few they were too detailed (5.7\%) or too extensive (3.8\%). On the other hand, for one-fourth of the respondents they were sufficient $(26.6 \%)$, understandable, legible (24.7\%), and easy to create (24\%). For every seventh person, they were concise (14.5\%), and for every eighth person they were adjusted to practical purposes $(12.6 \%) ; 7.6 \%$ of the respondents stated that finding diagnoses did not take them long (Fig. 3).

The language of formulating diagnoses was understandable for $42.4 \%$ of the respondents, $28.5 \%$ of respondents stated that it was necessary to think about them, for $24.7 \%$ of the respondents it was not always understandable, and for $4.4 \%$ of respondents it was not understandable. For over one-third of students, understanding diagnoses required the help of a teacher (39.2\%). As many as $62 \%$ did not have support from other students, who also did not always

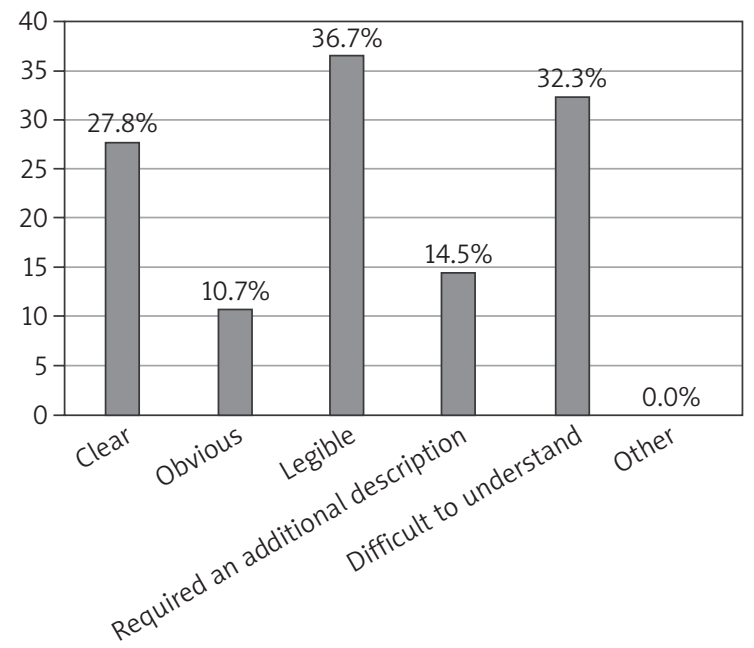

Figure 1. The layout of the content contained in the model

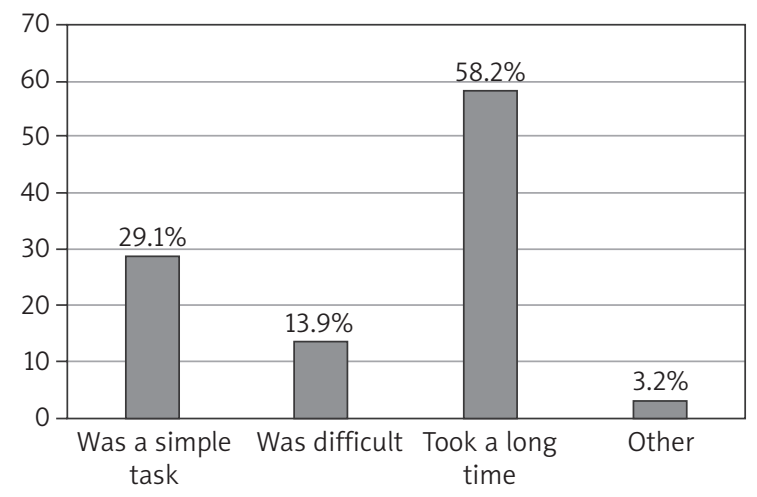

Figure 2. Searching for phrases in the opinion of respondents

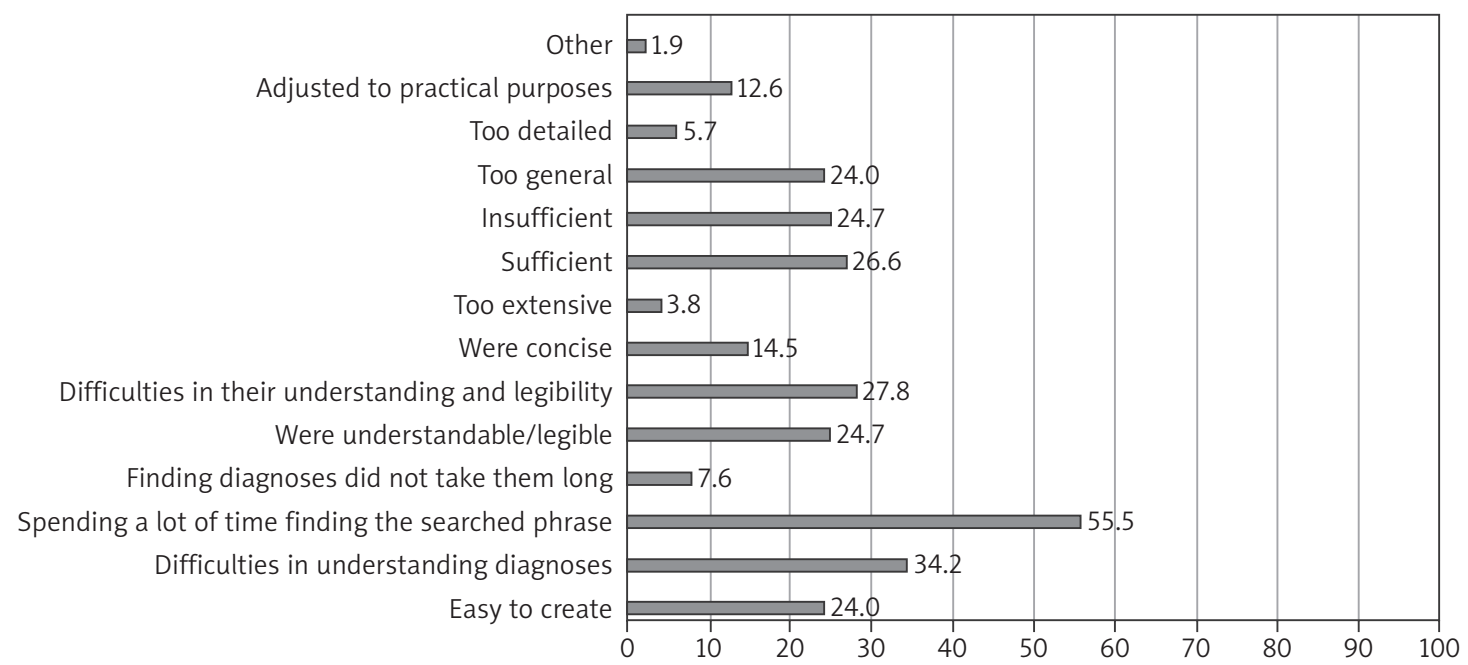

Figure 3. Diagnosis in the model in the opinion of the respondents (multiple choice question) 
understand the diagnosis. However, $31.6 \%$ of respondents had the impression that the other respondents always understood them in the same way, and only $6.4 \%$ had this impression rarely. The weak point of the model was the inability to enter a new diagnosis in the app for slightly more than half of the respondents (52.5\%). More than half of the respondents (58.2\%) stated that the list of interventions did not include all that the students had planned. For $41.8 \%$ of the respondents, the list of interventions was sufficient.

Over one-third of the surveyed students (36.1\%) stated that the suggested list of interventions was adequate for the diagnosis and was helpful (32.3\%). On the other hand, $26.5 \%$ of the respondents considered the list inadequate in relation to the diagnosis, and for $5.1 \%$ it was unnecessary.

Students were hindered by the inability to enter their own/new intervention (57\%). Another problem was the inability to modify interventions during the oncall time for more than half of the respondents (59.5\%).

More than half $(63.9 \%)$ of the respondents confirmed that it was possible to view the completed interventions. Unfortunately, $36.1 \%$ of the respondents could not do this. The possibility of delegating tasks or interventions was noticed by $32.3 \%$ of the respondents, $36.1 \%$ said they did not always have such possibility, and $31.6 \%$ answered that they could not delegate tasks. Slightly more than half of the respondents
(52\%) believed that the documentation allowed for the supervision of planned interventions. In comparison, $24 \%$ of the respondents stated that it was not always possible or responded negatively. Half of the respondents (50\%) said that they could choose the tools and equipment to carry out the planned interventions, $31.6 \%$ of the respondents did not always have such possibility, and $18.4 \%$ did not have such possibility. More than half $(54.4 \%)$ of the surveyed students stated that the results of the intervention did not always refer to a particular diagnosis, $38 \%$ of the respondents stated that the results of the intervention were well-defined, and $7.6 \%$ of the respondents chose the answer "other", for example: "inability to save interventions", "failure to enter intervention", "no intervention results".

Almost one-third of the surveyed students stated that the documentation allowed for dissemination of the results (31.6\%), but $43.1 \%$ of the respondents stated that it was not always possible, and $25.3 \%$ that it was not possible.

In the opinion of almost one-third of the respondents, the data analysis was useful (31.6\%) and understandable (30.4\%). However, it was illegible for onefourth of the respondents and useless for $11.4 \%$ (Fig. 4).

More than half of the surveyed students believed that electronic documentation did not facilitate or improve work (51.3\%) and had problems with the activity of all cards of documentation (51.3\%).

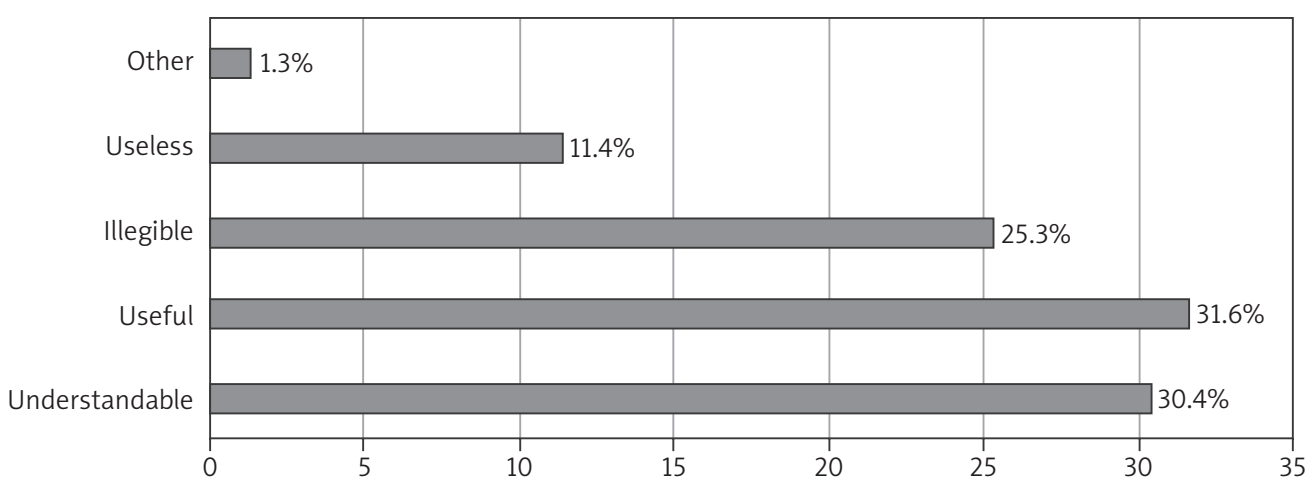

Figure 4. Opinion of respondents on data analysis

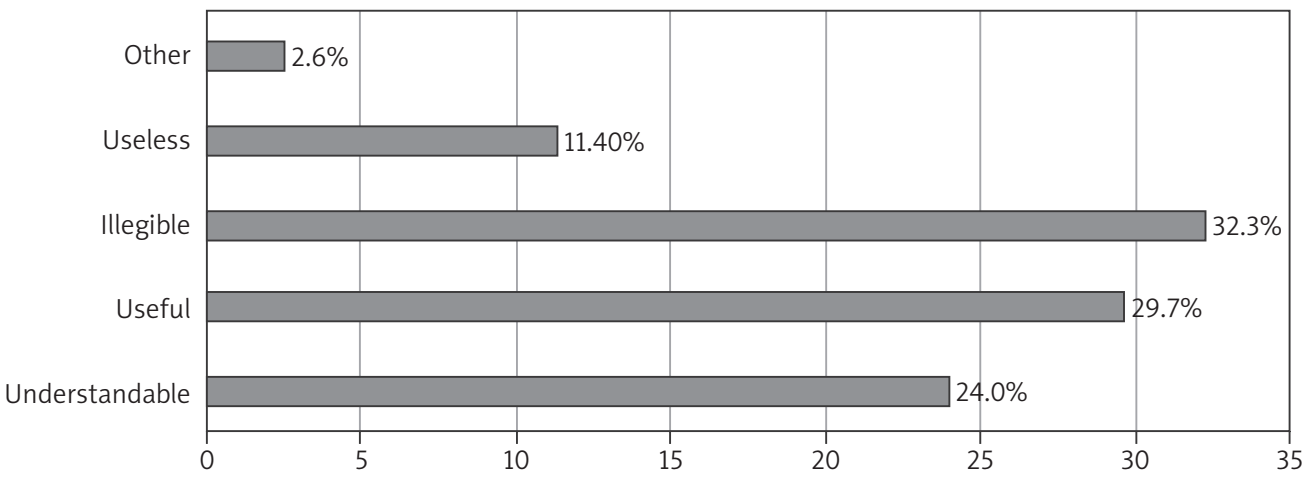

Figure 5. Opinion of the respondents on reference lists 
One-third of the respondents considered that the reference lists were illegible (32.3\%), and for every eighth person (11.4\%) they were useless. However, $29.7 \%$ of respondents found them useful, and $24 \%$ found them understandable (Fig. 5).

The survey ensured that the respondents had freedom of expression and were asked to share their opinions and thoughts on the electronic patient records. The respondents' responses were divided into positive and negative ones. Positive opinions related to the ease of collecting patient data and quick access to them ("It facilitates the work of a nurse. Everything is in one place", "It is a convenient and faster form of keeping patient records", "Electronic documentation will improve work after using it for a while", "Knowing the pattern and knowing where and how to search will be a convenience"); understanding e-documentation as a necessity resulting from the development of IT technologies facilitating the work of nursing staff, giving the possibility of eliminating errors in nursing work, as well as standardizing diagnosis and interventions ("Electronic documentation may eliminate difficulties when it comes to reading the handwriting of person interviewing. It can also standardize diagnosis and interventions", "It is a good idea because it allows constant access to the patient's file at any time and also improves the exchange of information, for example between doctors and nurses", "Electronic patient documentation makes it much easier to describe diagnoses and interventions", "It is the future of nursing", "Nowadays it is a must"). The simple use of the system and its transparency were also indicated. Unfortunately, negative opinions prevailed in the responses, and mainly concerned the following problems: the need to improve the e-documentation system ("refine the language and reference list", "lack of basic diagnoses and interventions", "diagnoses and some phrases are not understandable", "diagnoses are randomly added or removed", "the app is problematic, it was impossible to add/delete interventions, required a lot of time, it was not possible to use all the functions entrusted to us to perform the task"); improving the operation of the system resulting from difficulties with establishing a Wi-Fi connection ("the app freezes/does and not always work properly", "it could improve the work if the app would function as intended"); a lot of effort when filling in the documentation, simplifying the use of the app ("it is not understandable", "it is unreadable, it does not improve work", "it is complicated to use", "it makes nursing work difficult", "it is not very intuitive, filling in takes too much time", "some functions, such as fluctuations in body temperature during the day, required more time to think about how to enter the values so that the report shows a graph of these changes").
Students also had the opportunity to propose solutions to improve work with e-documentation. Students' suggestions mainly included: simplifying the language and operating the app, improving the page loading system and intuitively moving to the following tabs, giving the possibility to edit the entries made and modifying the interventions, creating a more understandable interview, and lists of diagnoses and interventions.

\section{DISCUSSION}

The introduction of electronic nursing documentation was aimed at facilitating the teaching-learning process for nursing students and nurses in connection with the use of ICNP. In this context, the use of technological resources may allow for their rapid development and modernization, creating a generation of professionals who use technologies to support their decisions [20]. This type of technological resource is intended to give dynamism to education and enable the development of skills and knowledge that can subsidize the solution of problems. Mota et al. [20] developed a mobile educational app for the use of ICNP, paying attention to the attractiveness, visual comfort, and dynamism of information. Barra and Dal Sasso [21] developed mobile educational applications for the use of ICNP in patient care in the intensive care unit, Silva, Evora and Cintra [22] in the care of children and adolescents. In this study, software called ADPIECare "Dorothea" [19] was used in relation to taking care of patients in an internal medicine ward.

The use of modern information technologies in health care may have several benefits. It revolutionizes and is accepted among specialists in particular fields of science. The rapid evolution of technological information fosters changes in the way of understanding content and promotes the construction of knowledge and the use of activating educational tools. It can be seen that teaching strategies based on activating teaching methods favour good practice - linking theory with practice, both in undergraduate studies and in continuing education of nursing staff. For the software to be successful, the information it provides must be attractive, and it should allow users to understand the information better and make it easier to recall them from associations [20]. A study in which 158 nursing students participated proved that the educational technology used is appropriate for them, and it supports the collection of biopsychosocial and spiritual data about patients and their deficits in terms of individual health needs. On the other hand, it facilitates, to a lesser extent, nursing diagnoses and the development of plans, as well as documenting their implementation, and ongoing and final evaluation. The reason for the dif- 
ficulties in making nursing diagnoses and developing plans can be explained by the lack of experience in patient care and only basic knowledge acquired during the first year of studies. Electronic documentation of the nursing process is a tool that facilitates the learning process but, at the moment, it is a tool that is not very flexible in the educational environment, which emphasizes the importance of software development. It supports training in diagnostic reasoning and consequently facilitates its use in clinical practice. It stimulates the active participation of nursing students in the learning process and their interests, critical thinking, reflection, learning from experience, argumentation, and linking theory with practice. In addition, it provides students with a safe clinical decision-making environment without risking harm to the actual user. It also challenges students' curiosity. This information technology promotes some students' characteristics, such as the pace of their learning and self-organization. The software opens the door to the belief that its use contributes to improving the teaching-learning process and supports clinical decision-making by nursing students, although it requires further refinement.

There is a need for dynamic, interactive, and innovative strategies implemented in nurse education, especially with regard to ICNP, so that nursing can develop as a science, to promote the improvement of learning methods, to arouse interest in the development of new technologies adapted to the theoretical-practical area of knowledge, and to promote the improvement of quality of care and its documenting.

\section{LIMITATIONS}

We recognize that the main limitations of this study are that the study was conducted in one location and had a small sample size. The presence of limitations typical of the methodology requires that the results should be treated with caution. In future research, the study area and sample size should be expanded.

\section{CONTRIBUTION TO THE FIELD OF NURSING, PUBLIC HEALTH}

This study predicts benefits such as the ability to expand information on this classification system of nursing diagnosis according to ICNP, both for undergraduate students and professionals in the labour market, facilitating the communication process between nurses by promoting a unified language, using the software in clinical practice, independently of the user's culture or geographic region. The study highlights the usability of this digital asset in healthcare and academic contexts to promote clinical evaluation and decision-making.

\section{CONCLUSIONS}

The conclusions are as follows:

- students saw the reasons behind keeping electronic documentation of the nursing process based on the classification of nursing diagnoses and the ICNP $^{\circledast}$ dictionary of terms, provided that its operation was improved,

- they saw the advantages of electronic patient records,

- they pointed out the disadvantages of electronic patient documentation,

- in the opinion of students, the Dorothea application can be used as a tool to improve the documentation of the work of students/nurses after introducing minor corrections.

Moreover, students indicated elements of electronic documentation that need to be refined so that they are understandable, clear, and unambiguous for the users.

\section{Disclosure}

The authors declare no conflict of interest.

\section{References}

1. Kilańska D. Elektroniczny record pacjenta w opinii pielęgniarek. Implikacje do dydaktyki - wykorzystanie narzędzi IT w nauczaniu klasyfikacji ICNP. Probl Pielęg 2017; 25: 69-76.

2. Ausili D, Sironi C, Rasero L, et al. Measuring elderly care through the use of a nursing conceptual model and the international classification for nursing practice. Int J Nurs Knowl 2012; 23: 146-152.

3. Baernholdt M, Lang NM. Why an ICNP? Links among quality, information and policy. Int Nurs Rev 2003; 50: 73-78.

4. Kilańska D, Gaworska-Krzemińska A, Grabowska H, et al. A case study of the introduction of the International Classification for Nursing Practice in Poland. Int Nurs Rev 2016; 63: 361-371.

5. Foryś Z, Dębska G, Matusiak M, Kilańska DM. Wiedza i akceptacja pielęgniarek dotycząca wykorzystania i prowadzenia dokumentacji medycznej opartej na wytycznych Międzynarodowej Rady Pielęgniarek - Międzynarodowej Klasyfikacji Praktyki Pielęgniarskiej ICNP. Probl Pielęg 2017; 25: 227-232.

6. Kilańska D (Ed.). Międzynarodowa Klasyfikacja Praktyki Pielęgniarskiej ICNP w praktyce pielęgniarskiej. PZWL, Warszawa 2014.

7. Seminarium „STOP wykluczeniu w pielęgniarstwie. Elektroniczna dokumentacja medyczna: doświadczenia z wdrażania i wykorzystania ICNP w Elektronicznym Rekordzie Pacjenta (EHR) w Polsce". Uniwersytet Medyczny, Łódź 2015.

8. Dobrowolska B, Ikwanty K. Wykorzystanie Międzynarodowej Klasyfikacji Praktyki Pielęgniarskiej (ICNP) w diagnozowaniu pacjenta Oddziału Intensywnej Opieki Medycznej. Piel XXI wieku 2012; 1: 67-71.

9. Kilańska D, Staszewska M, Urbanek N, et al. Planowanie opieki według międzynarodowego standardu ICNP w Podstawowej Opiece Zdrowotnej - studium przypadku. Probl Pielęg 2014; 22: 539-545.

10. Kilańska D, Staszewska M, Urbanek N, et al. Planowanie opieki według międzynarodowego standardu ICNP w Podstawowej Opiece Zdrowotnej - studium przypadku jednostki i rodziny. Cz. II. Probl Pielęg 2014; 22: 546-552. 
11. Kuberka I, Kołtuniuk A, Michalak M, et al. Zastosowanie Międzynarodowej Klasyfikacji Praktyki Pielęgniarskiej ICNP w opiece okołooperacyjnej nad pacjentem z rozpoznanym chrzęstniakomięsakiem kości krzyżowej. Współczesne Pielęgniarstwo i Ochrona Zdrowia 2016; 5: 118-120.

12. Grabowska H, Grabowski W, Gaworska-Krzemińska A. Mapowanie fraz opisujących diagnozy i interwencje pielęgniarskie w opiece nad chorym z cukrzycą z wykorzystaniem ICNP. Piel XXI wieku 2014; 3: 37-41.

13. Grabowska H, Grabowski W. Zakres interwencji pielęgniarskich w opiece nad chorym w okresie okołooperacyjnym z wykorzystaniem Międzynarodowej Klasyfikacji Praktyki Pielęgniarskiej. Probl Pielęg 2014; 22: 385-389.

14. Grabowska H, Grabowski W. Problemy pielęgnacyjne chorych w okresie pooperacyjnym w ujęciu Międzynarodowej Klasyfikacji Praktyki Pielęgniarskiej. Probl Pielęg 2014; 22: 379-384.

15. Grabowska H, Grabowski W. Wykorzystanie ICNP w opiece pielęgniarskiej nad pacjentem z nadciśnieniem tętniczym. Probl Pielęg 2014; 22: 107-112.

16. Habel A, Cierzniakowska K, Grabowska H, et al. Propozycja realizacji diagnoz pielęgniarskich z wykorzystaniem Międzynarodowej Klasyfikacji Praktyki Pielęgniarskiej u chorego operowanego z powodu przepukliny pachwinowej. Piel Chir Angiol 2011; 5: 187-202.

17. Grabowska H. Zakres wykorzystania ICNP w nauczaniu podstaw pielęgniarstwa w uczelniach polskich. Doniesienia wstępne. Probl Pielęg 2017; 25: 77-81.

18. Avelino CC, Costa LC, Buchhorn SM, et al. Teaching-learning evaluation on the ICNP using virtual learning environment. Rev Bras Enferm 2017; 70: 602-609.

19. System dokumentacji pielęgniarskiej "ADPIECare Dorothea”. https://pielegniarki.umed.pl/ (29.04.2017).

20. Mota NP, de Araújo Vieira CM, Nascimento MNR, et al. Mobile application for the teaching of the International Classification for Nursing Practice. Rev Bras Enferm 2019; 72: 1020-1027.

21. Barra DCC, Dal Sasso GTM. Mobile bedside technology: computerized nursing processes in intensive care unit from ICNP® 1.0. Texto \& Contexto Enfermagem 2010; 19: 54-63.

22. Silva KL, Evora YD, Cintra CS. Software development to support decision making in the selection of nursing diagnoses and interventions for children and adolescents. Rev Lat Am Enfermagern 2015; 23: 927-935. 